\title{
Study on Intangible Welfare of Large State-owned Enterprises
}

\author{
Yang Dang \\ School of Economic \\ Changchun University of Finance and Economic \\ Changchun, China 130012
}

\author{
Yuzhe Wang* \\ School of Economic \\ Changchun University of Finance and Economic \\ Changchun, China 130012 \\ *Corresponding Author
}

\author{
Mo Zhou \\ School of Economic \\ Changchun University of Finance and Economic \\ Changchun, China 130012
}

\begin{abstract}
Intangible welfare refers to the welfare that cannot be reflected in traditional auditing report or be found in any means which is different from the "tangible welfare" stipulated by state laws and regulations. Intangible welfare is invisible, diversified and regulation-violating. It is embodied in intangible housing welfare, daily consumption welfare, financial speculation welfare and knowledge product welfare etc. To prevent the happening of intangible welfare among state-owned enterprises, it is necessary to establish an auditing warning model based on risk-orientation, reinforce the government's macro guidance to the enterprises and set up effective self-regulative scheme.
\end{abstract}

Keywords-state-owned enterprise; intangible welfare; problem; study

\section{INTRODUCTION}

May 10 in 2013, National Audit Office of the People's Republic of China successively issued annually financial balance status reports in 2011 of 13 state-owned enterprises. The results revealed that many state-owned enterprises made use of state-owned funds to offer welfares to their employees. Among them, 3 state-owned banks violated the regulations and granted welfares which totaled $¥ 22$ billion (about $\$ 3.27$ billion); 10 state-owned enterprises also illegally granted welfares which were over $¥ 85$ billion (about $\$ 12.63$ billion). According to investigation, all state-owned enterprises in China had illegally given a large sum of welfares totaled over $¥ 1$ trillion (about $\$ 0.15$ trillion) in 2012 . Academically, the welfare that is beyond state regulations is "intangible welfare" which is different from the "tangible welfare" stipulated by state laws and regulations.

\section{FUNDAMENTAL FEATURES OF THE INTANGIBLE WELFARE IN STATE-OWNED ENTERPRISES}

"Intangible welfare" is a defined conclusion towards social welfares. Based on the quantity and quality of illegal welfares granted by state-owned enterprises, it is concluded that their intangible welfare has the following features.

\section{A. Invisibility}

Surveying the channels for illegal welfares, it is found that its feature of being invisible caused the inobservance from the authorities. A welfare policy which is mainly macro-controlled by the government is generally issued and enhanced by administrative and legal methods.

\section{B. Regulation-violation}

There are two kinds of regulations: law and department regulations. In the survey of economic cases, the differences between the two should be clarified. The reason of being clear with their differences is that it is criminal responsibility of violating the former and it is administrative responsibility of violating the latter. Responsibility culture functioned behind the surface, restricting administrative staff's professional integrity and working habits as well as potentially providing opportunities for officers or administrator to exculpate them.

\section{MANIFESTATION OF THE INTANGIBLE WELFARE IN STATE-OWNED ENTERPRISES}

Intangible welfare can be classified into different categories by different ways, such as intangible welfare and tangible welfare, intangible legal welfare and intangible illegal welfare, intangible welfare and tangible welfare etc. This paper focuses on the main manifestations of intangible welfare of state-owned enterprises.

\section{A. Daily Consumption Welfare}

In Ancient Society, L.H. Morgen pointed out that human is a gregarious animal. Human is born with gregariousness. It is in human nature. Individual's consumption is always based on other people's production, which generates the 
thoughts that "it is natural to raise one's own social welfare". This nature not only explained the beginning of the welfare, but also caused the fact that illegal welfares in state-owned enterprises have a basic social foundation.

\section{B. Financial Speculation Welfare}

Market speculation is the inner motivation to have illegal welfare among state-owned enterprises. It is also a major economic reason for mid-level management personnel to explore enterprise management ability. Being strongly driven by the administrators, welfares came in other forms such as giving option, transferring stock right, discountrate, fund bonus etc.

\section{CAUSE ANALYSIS OF THE INTANGIBLE WELFARE IN STATE-OWNED ENTERPRISES}

How does the welfare that cannot be revealed by traditional audit report form? There are the following reasons.

\section{A. System Element}

As a result of "government hand" participating market in a nonstandard phase, it is hard to withdraw after long integration. It is also because that the market began in power transformation phase, therefore, market couldn't be separated from the government due to long delay.

\section{B. Benefit Element}

The biggest motivation of intangible welfare is the material gain relation chain promoted by economic benefit. Without sharing benefit, welfare will lose its economic foundation and become meaningless.

\section{CONCLUSION}

In recent years, aiming to deal with the malpractice of the management in state-owned enterprises, National Audit Office began to promote risk-oriented auditing mode since 2007. This mode breaks away from the restrictions of bills, account book and reporting form, is based on risk evaluation of the audited enterprise, and comprehensively analyses all sorts of elements that influenced the audited enterprise. Considering the realistic factor of current market in China, there are the following two ways of handling intangible welfare problem.

\section{A. Building Risk-oriented Auditing Mode to Prevent Intangible Welfare from Happening}

Martin put forward Logistic Mode in 1977.This mode set indicators that can reflect enterprise's profitability, debt paying ability, capital operating ability and growth capability. Practice has shown that this mode is relatively accurate in predicting potential enterprise risks and has been applying by National Audit Office. In addition, by setting enterprise risk management which includes 8 elements, 4 targets and 4 categories, COSO-ERM has also established a 3-dimension mode that assesses visible and invisible risk issues comprehensively in an enterprise. This is the best mode that is used internationally to control unusual welfare of an enterprise.

\section{B. Government Establishing Intervening Mechanism for Enterprise Risks Actively to Prevent Intangible Welfare in State-owned Enterprises from Happening}

The government should not only enact different kinds of effective policies, but also intervene and guide risks. The appearance of intangible welfare in state-owned enterprises is usually formed in the process of nation power transformation and governments massive intervene to the market.

\section{REFERENCES}

[1] Wang Daocheng. Implementing New Concept, Carrying out New Measures, Perfecting and Developing Internal Auditing Standard System in New Situation.Document of China Internal Auditing Association [D]. Issued by CIAA[2006]16.

[2] David McName: Risk Based Auditing, Internal Auditor [J]. 1997, 8.

[3] Roth James. Best Practices: Value-Added Approaches of Four Innovative Audit ng Departments [M]. 2000,1. 